\title{
Influence of Transaction Transfer Pricing Policies on Corporate Organizations Tax in Nigeria
}

\author{
Osho, Augustine E. Ph.D. ${ }^{1}$, Ilori, Folusho Olayemi ${ }^{2 *}$ \\ ${ }^{1,2}$ Department of Accounting, College of Social and Management Sciences, Achievers University, Owo, Nigeria
}

\begin{abstract}
This study aimed to discuss the influence of transaction transfer pricing on corporate organizations tax in Nigeria. A descriptive research model was adopted. Secondary data were obtained from KPMG International (Tax) Bulletin report on fifty (50) major corporate organizations in Nigeria for 2014 to 2018 concerning transaction transfer pricing policies in terms of its influence on the organizations' business growths, tax rate, profit rate and tax liability. Results obtained for the study showed that transaction transfer pricing policies have a positive influence on the business growth on corporate organizations in Nigeria. It was recommended that corporate organizations should employ adequate measure that safeguards and avoid costly error in the implementation of transaction transfer pricing policies.
\end{abstract}

Keywords: corporate organizations tax, transfer pricing, transfer pricing policies.

DOI: $10.7176 /$ RJFA/11-6-07

Publication date:March $31^{\text {st }} 2020$

\section{Introduction}

Transaction transfer pricing is the price charged by one member of a corporate organizations to another member of the same organization for the provision of goods or services or the use of a property which includes intangible property (Nilufer, 2012). Hence, it could be said to be the price applied to inter-corporate organization transactions. There have been studies in time past showing that inter-corporate organizations transactions are growing very rapidly with a greater number from international terrains (Adams and Drtina, 2010; Dürr \& Göx, 2013). Transaction transfer pricing is the price transaction between related corporate organizations (such as a parent company and its foreign control) in an in a joint venture transaction (McKinley \& Owsley, 2013). These transactions can include the sales of products, the provision of a service, the lending of money, the use of assets among others. Transfer pricing is also relevant for the allocation of profits between the various legal entities and branches of multinational companies (Allen, 1999). Transaction transfer pricing is often presented as a tax avoidance technique, this is inaccurate as it only refers to a set of substantive and administrative regulatory requirements imposed by governments on certain taxpayers (Falk, 2010). The transaction transfer pricing policies, therefore, allow tax authorities to adjust prices for most intra-corporate organizations' transactions which include the transfers of tangible or intangible properties, services and loans (Cooper, Fox, Leoprick, Mohindra, 2016).

Arm's length principle cannot be overlooked when discussing transaction transfer pricing. Arm's length principle states that requires associated enterprises to charge the same prices, royalties and other fees concerning a controlled transaction that would be charged by independent parties in an uncontrolled transaction is otherwise comparable circumstances. Hence, it is the condition or the fact that the parties to a transaction are independent and on an equal footing (Tebogo, 2011).

This could be emphasized that the prices and conditions applied between related corporate organizations should be equal to the prices and conditions charged between independent ones. Influence of the transfer pricing specifically impose the stress on corporate organizations which involved in the registered in the same group as charges of transaction transfer pricing will affect the profitability of companies related in the same group.

Transaction transfer pricing does not only relate to pricing within the corporate organizations, but other conditions of transactions such as delivery, warranty and payment terms are also emphasized as part of the procedures. Transaction transfer price influences tax policy within the corporate organization. The transfer price considers the price established when one part of an Organization provides tangible and intangible goods to another part of the same organization in two or more countries (Gupta, 2012). The transaction transfer pricing strategy is widely used by corporate organizations as a way to reduce tax liability. Organizations recognize most of the profits in countries with low tax rates, which reduces the tax burden on the organization as a whole (Adams et al., 2010).

Transaction transfer pricing helps incorporate organizations' decision-making structures which include the reduction in corporate income tax payments or duties and transferring income from countries with bans or limitations on profit repatriation (Tebogo, 2011). The corporate organizations' policy regarding transaction transfer pricing is based on many factors, such as the fiscal aspects of countries involved in the cross-border activity of member companies of the group, the currency legislation, the political and economic risks and the price level in the host country among others.

There are several challenges facing transaction transfer pricing policies with corporate organizations due to the current systems of corporate taxes, especially in Nigeria and several African countries. These gaps allow 
corporate organizations with cross-border activity to avoid the taxes because of variation in rules under which each subsidiary subject to tax rates on income taxes based on the activity in the host country. This could cause disputes between tax authorities and taxpayers which may arise in many areas as tax authority may adopt an unfavorable economic method or an unfavorable tax characterization to the corporate organizations. Economic globalization and integration are great menaces in verifying actual transfer pricing used by the corporate organizations.

\subsection{Literature Review}

\subsection{Conceptual Framework}

\subsubsection{Concept of transfer pricing}

Globalization and international trade have been identified as the key factors that increase multinational companies ' transfer pricing activities to enter markets, especially where there are limited numbers of local producers (Tanzi, 2000). Many of these transfer pricing transactions are between foreign multinational corporations within a group, thus greatly boosting international trade. Transfer pricing is known as the price charged by a multinational company sales department, division or subsidiary for a product or service sold to a purchasing department or subsidiary of the same multinational company (Mutua, 2012).

The transfer prices adopted by multinational division or branch that directly affect the profits posted in their respective host countries by each of these units. Therefore, these transfer rates present an opportunity to move income from high-tax countries to participants in low-tax countries to related groups. Transfer pricing in crossborder transactions is regulated by the rule of arms-length stating that the terms and conditions of exchange between units of the same group should be the one stated as if they were not members of the same group (Dean, Feucht \& Smith 2008). Those include transactions taking place within a network of separate companies.

2.1.2 Transfer pricing policies

A business entity's transfer pricing policy of exchanging rates relies on the one followed by the state and this varies across the globe. A country's selection of any policy will depend on its relative merits and demerits, as well as other internal and external factors. Such policies can be classified roughly into three categories:

- Cost-based transfer pricing policy: This form of transfer pricing strategy is considered suitable for conditions where market prices are not available or are not appropriate for similar products. In this way, business entities ' divisions in inter-related business transactions are called cost-centered (Oyunda, 2015). There are also perceived to be better control of costs, effective decision-making and assessment of performance. Inflation, however, may cause the cost to be high and the buying agencies reject it.

- Market-based transfer pricing policy: This type of transfer pricing policy is considered useful for more decentralized businesses. A market price-based transfer pricing policy has significant appeal to many business entities. With an objective measure of the quality of the transferred item, this form of the policy was considered fair. It also raises the stress and expectations for internal competition. As regards external incentives, this calculates divisional gain (Williams, 2007). A business can accomplish its targets autonomously by using market-based transfer pricing strategies in perfectly competitive markets.

- Negotiated-based transfer pricing policy: When the demand is open, negotiated transfer pricing policies are considered to be optimal for adoption. These are known as the product of the negotiation process between the selling companies and the purchasing companies. Such transfer pricing policies depend solely on the negotiating strengths of both parties, thereby reducing misunderstandings and conflicts between the selling and purchasing companies (Dubin, 2004).

\subsubsection{Corporate organization tax and business growth}

A corporate organization tax is a direct tax imposed by a jurisdiction on the income or capital of corporations or analogous legal entities (Liu, 2011). Many countries impose such taxes at the national level, and a similar tax may be imposed at state or local levels. The taxes may also be referred to as income tax or capital tax. Corporate organization income subject to tax is often determined much like taxable income for individual taxpayers. Generally, the tax is imposed on net profits. In some jurisdictions, rules for taxing corporate organizations may differ significantly from rules for taxing individuals (Clausing, 2012). Certain corporate acts, like reorganizations, may not be taxed. Some types of entities may be exempt from tax. Corporate tax rates vary widely by country, leading some corporations to shield earnings within offshore subsidiaries or to domicile within countries with lower tax rates which may have adverse effects on business growth in such countries (Clausing, 2012). However, it is important to point out that if corporate tax rate reductions occur simultaneously with other measures that raise the user cost of capital, the net effect may not induce additional investment or output (Gupta, 2012). Countries may tax corporations on its net profit and may also tax shareholders when the corporation pays a dividend. Where dividends are taxed, a corporation may be required to withhold tax before the dividend is distributed.

2.1.4 Profit margin influence on corporate organizations

The profit margin is an accounting measure designed to gauge the financial health of a business or industry. In general, it is defined as the ratio of profits earned to total sales receipts (or costs) over some defined period. The profit margin is a measure of the amount of profit accruing to a firm from the sale of a product or service (Falk, 
2010). The profit margin is the gap between the revenue earned and the cost of goods sold, it varies depending on the industry and the firm. It also provides an indication of efficiency in that it captures the amount of surplus generated per unit of the product or service sold. To generate a sizeable profit margin, a company must operate efficiently enough to recover not only the costs of the product or service sold, operating expenses, and the costs of debt, but also to provide compensation for its owners in exchange for their acceptance of risk. There are higher profit margins reported for organizations implementing transaction transfer policies thereby ensuring appropriate business growth (OECD, 2010).

2.1.5 Corporate tax liability

Corporate tax liability is the total amount of tax debt owed by a corporate organization to a taxing authority like the Internal Revenue Service (IRS). Tax liabilities are incurred due to earning income, gain on the sale of an asset or other taxable events. Taxes are imposed by a variety of taxing authorities, including federal, state and local governments within a country or to corporate organizations transacting within countries (Uthman, 2016). When a taxable event occurs, the taxpayer needs to know the tax base for the event and the rate of tax on the tax base. The tax liability doesn't just include the current year; instead, it factors in all years that the entity may owe taxes. That means that if there are back taxes (any taxes that remain unpaid from previous years) due, those are added to the tax liability as well. One of the common tax liabilities among corporate organizations is sales tax liabilities and transaction transfer pricing tax liabilities, a tax debt incurs when corporate organizations tend to procrastinate on tax payment after a successful transaction. This hinders actual assessment of the business growth of the corporate organization as values reported as profits may be tax debts.

2.1.6 Challenges of Transaction Transfer Pricing

Several challenges facing transaction transfer pricing policies with corporate organizations have been reported and a major challenge is one that allows corporate organizations with cross-border activity to avoid the taxes because of variation in rules under which each subsidiary subject to tax rates on income taxes based on the activity in the host country. This could cause disputes between tax authorities and taxpayers which may arise in many areas as tax authority may adopt an unfavorable economic method or an unfavorable tax characterization to the corporate organizations. Economic globalization and integration are great menaces in verifying actual transfer pricing used by the corporate organizations (Adum, 2015). With this, it will be complex to determine accurate transaction transfer pricing due to increase in the presence of transactions among new and emerging corporate organizations. There may also be challenges in ensuring consistency in the application of global transaction transfer pricing policies on corporate organizations negligence to the host's tax requirements (KPMG, 2017). It will be difficult also to avoid double taxation impact of transfer pricing adjustment carried out within a country. Finally, application of Arm's length principle in transaction transfer pricing is tedious as its difficult in identifying all the transactions that are necessary for the calculation.

2.1.7 Conceptual framework on transaction transfer pricing policies on Corporate Organizations Tax in Nigeria

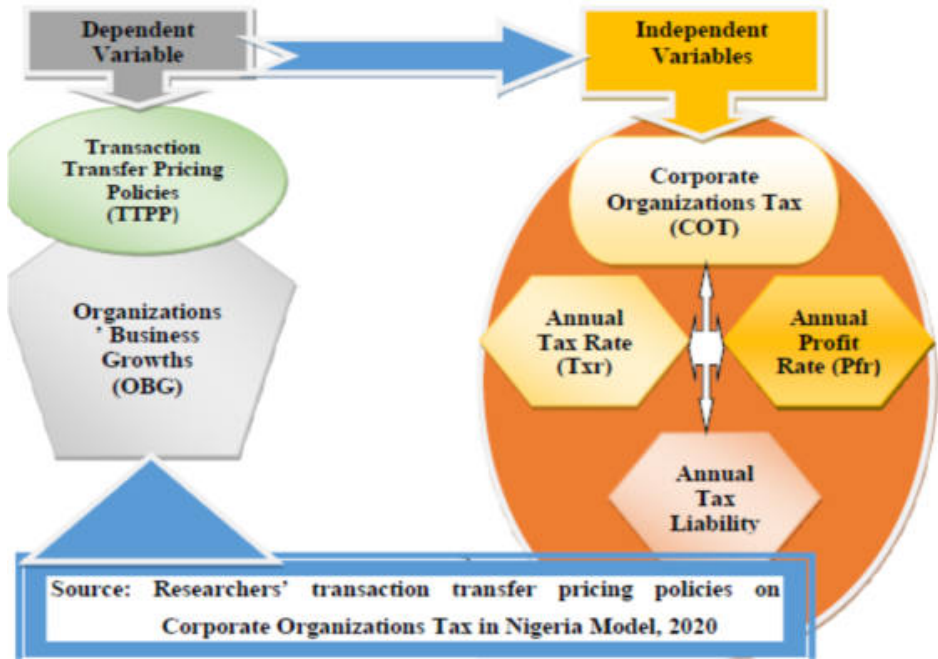

Organizations' Business Growths (OBG): Growth objectives are what every company seeks to achieve, regardless of its size, as it is a sign of success and development. A growing business is one with a higher survival rate, a higher reputation, and increasing annual profit estimates (Lipton, 2003). Crosby (1990) said the growth of business organization is a mechanism through which the structure of an entity of the business system increases the number of its functions and relations. The business growth of organizations is essentially a quantitative process compared to other growths required in a business entity's survival.

Annual Tax Rate (Txr): The government usually taxes its citizens and all enterprises related to the country to 
help build and maintain the infrastructure used in the country. All raised taxes are used to develop the economy and all those who reside in it. The tax rate adopted is the ratio that is usually expressed as a percentage, this is the rate at which such businesses or entities are taxed (Piper, 2014). Therefore, the amount at a specified annual rate at which a person and company are taxed is an annual tax rate. Such rates of tax vary from one country to another in business transactions. Some countries adopt a progressive tax system, while others use tax rates that are regressive or proportional (Piper, 2014).

Annual Profit Rate (Pfr): Profit defines the financial benefit achieved if the revenue generated from a business activity exceeds the expenditures, costs, and taxes involved in maintaining the activity in question (Carbaugh, 2006), thus measuring profit as total revenue less total expenses. An organization's income could be measured as the remaining amount after all the costs and deductions have been subtracted from gross revenue. In this regard, expenses and allowances and allowances include the direct costs of selling goods, operating expenses such as selling, administrative and general expenses and non-operating expenses such as depreciation, financing charges and taxes. Annual profit is a key measure of success and quality of a company such as a full year development. The annual rate of profit is expressed as a percentage of sales or profit margin that can be used to compare the earnings of the year with previous years or other companies' profit margins in the same industry (Adams \& Drtina, 2010). It allows business entities in future years to estimate average annual income and annual stakeholder return price.

Annual Tax Liability (Txl): tax liability is the amount of tax debt owed to a taxing authority such as the internal revenue service by an individual, company or other organization (Steven, 2011). It is the amount of tax paid by a business entity or individual on the basis of current tax laws. It is the amount of tax paid by a business entity or individual on the basis of current tax laws. For organizations involved in transactional transactions, it is necessary to understand the tax rates for each country involved in such business in order to avoid incurring liabilities. Tax liability is a legally binding obligation to an agency and is a perpetual liability (these are short-term liabilities to be settled within one year). In normal business activities, annual tax liabilities are incurred and failure to pay a tax liability can result in back taxes, a tax lien, fines, interest and even imprisonment (Steven, 2011).

\subsection{Theoretical Framework}

Transfer pricing policies are quite similar globally as implemented in various corporate organizations (AbuSerdaneh, Al-Okdeh \& Gauher, 2008). The Organization for Economic Cooperation and Development (OECD) transaction transfer pricing guidelines was adopted in the present study. The OECD guideline provides five common transfer pricing methods that are accepted by nearly all tax authorities (OECD, 2010). These five transaction transfer pricing methods are further divided into two categories namely:

i. Traditional transaction transfer pricing methods

ii. Transactional transfer pricing profit methods

2.2.1 Traditional Transaction Transfer Pricing Methods

Traditional transaction transfer pricing methods are known to be the greatest suitable methods of applying the Arm's length principle (OECD, 2010). The traditional transaction transfer pricing method evaluates the conditions of transactions between independent enterprises and compares these with those of a controlled transaction. The adopted OECD guideline recognizes that the traditional transaction transfer pricing methods are divided into three types:

(a) The Comparable Uncontrolled Price (CUP) Method

The CUP Method compares the terms and conditions which includes the price of a controlled transaction to those of a third party transaction. Transaction transfer pricing policy under this method is determined by comparing the market price that is charged in a related company with the other nonrelated company in the same transaction (Savita, 2003). This third-party transaction (method) is clearly of two categories, namely:

- Internal CUP - a transaction between a taxpayer and an independent enterprise

- External CUP - a transaction between two independent enterprises

(b) The Resale Price (RP) Method

This resale pricing method is applied to control distributors. Initially, the price at which an associated enterprise sells a product to a third party is first considered. This price is called a resale price (RP). Thereafter, the resale price is reduced with a gross margin known as the resale price margin. This method is determined by comparing gross margins in comparable uncontrolled transactions and the deduction of the costs associated with the purchase of the product such as transaction taxes. The marketing unit of an organization also uses the resale price method when a small value is added and there are no major manufacturing operations. The outcome of this process can be regarded as an Arm's length price for the controlled transaction between associated enterprises (Singh, 2015). The Resale Price Method is also known as the Resale Minus Method (RMM).

(c) The Cost Plus (CP) Method

In the cost-plus method, the transfer price is determined by comparing the sales cost to the gross profit proportion (Blocher, Stout, Cokins\& Chen, 2006). The procedure for that should be followed to adopt this method effectively 
is described below:

i. Determine the costs incurred by the supplier in a controlled transaction for products transferred to an associated purchaser

ii. Add appropriate mark-up has to the cost to make an appropriate profit in the functions performed

iii. Consider a price at Arm's length

2.2.2 Transactional Profit Methods

In the transactional profit method, the focus is not the transfer price but the profit gained as a result of transactions between the two related corporate organizations doing the transactions (OECD, 2018). This method is sparingly used compared to the traditional method however more often used in the absence of detailed information about transactions; this is because the application of the traditional transaction methods requires detailed information which often is not accessible. The net operating profits realized from controlled transactions is measured, while the profit level is compared to the profit level realized by independent corporate organizations involved in the transactions. Transactional profit methods are divided into two categories.

(a) Net Margin (NM) Method

In this method, the net profit of a controlled transaction of an associated enterprise is first determined and then compared with comparable uncontrolled transactions of independent enterprises (OECD, 2010). The net margin of similar companies in similar business circumstances is compared with the net margin from transactions between related companies. This method is effective when transactions carried out between the corporate organizations are broadly similar. This similar transaction can be between an associated enterprise and an independent enterprise or between two independent enterprises.

(b) The Profit Split Method

This method can be adopted is transaction transfer pricing if associated organization engage in very interrelated transactions. Therefore, they cannot be examined on a separate basis. Hence, these associated organizations normally agree to split the profits. The procedure is to determine the profit-split formula among related organizations participating in that particular transaction. This must be considered under the current market circumstances while the stakes in profits are assigned to interrelated companies (OECD, 2010). Two main approaches can be taken for splitting profits. These are:

- Contribution analysis: The combined profits are divided based on the relative value of the functions performed by each of the related entities within the controlled transaction (considering assets used and risks assumed).

- Residual analysis: The combined profits are divided into two stages. First, each entity is allocated arm's length compensation for its functions and contribution to the controlled transaction. Second, any remaining profit or loss after the first stage is divided based on analysis of the facts and circumstances of the transaction.

\subsection{Review of Empirical Framework}

As earlier discussed, transaction transfer pricing is the price paid from one organization to another for a product or service when both are owned and report to the same parent company (Nulifer, 2012; McKinley and Owsley, 2013), as well as its relevancy in the allocation of profits between the various organizations (Allen, 1999). It dictates the approach taken by the two organizations performing a transaction when determining the price for the product or service (Abu-Serdaneh et al., 2008; OECD, 2010). Corporate organizations incorporate different transfer pricing policies to achieve different objectives; some of these commonly adopted policies are discussed in this present study.

Cost-plus pricing policy involves adding a markup (direct material cost, direct labour cost and overhead costs) of a product to the cost of goods and services to arrive at a selling price (Ordu \& Anele, 2015). In this policy model, it is quite easy to derive a product price using this method, though the overhead allocation method should be well defined among the corporation organizations involved in the transaction, to be consistent in calculating the prices of the products and there are assured transaction profits in every transaction. However, the method is based on historical costs and may likely include as many costs as possible in the contract so that it can be reimbursed.

Contribution margin transfer pricing policy represents the incremental money generated for each product sold after deducting the variable portion of the firm's costs; it is calculated as the selling price per unit, minus the variable cost per unit (OECD, 2010). This policy in transaction pricing indicates how a particular product contributes to the overall profit of the organization. It provides one way to show the profit potential of a particular product offered by a company and shows the portion of sales that helps to cover the company's fixed costs. While the remaining revenue left after covering fixed costs is the profit generated. The merit is that all participating organization during the transaction will share the contribution margin while the demerit is that the transfer price may be unknown to participating organizations until the product is sold to a consumer.

A negotiated transfer pricing policy results from discussions between the selling and buying divisions to allow some level of freedom to these units in determining the price to use for inter-company transfers (Aaron \& Stefan, 
1995). Negotiated transfer prices have many important advantages at it preserves the autonomy of the divisions and ensures effective decentralization. This policy also allows participating organizations access to adequate information about the potential costs and benefits of the transactions.

External market policy a policy that allows investment opportunities which are offered outside the jurisdiction of a specific country. It's a policy that permits investments to be put up for sale in multiple countries simultaneously, allowing international investors to pick and choose from for inter-organization transactions (Mutua, 2012). The advantage of this policy is that all transactions occur at the higher market price, allowing the organization to maximize profits. The flaws of this policy are that the company loses control over quality when purchasing from outside the company and it is less closely regulated because there are fewer regulations and the regulations can be inconsistent and confusing (OECD, 2019).

\subsection{Methods}

In this study, descriptive research model was adopted. The idea behind this type of research is to study frequencies, averages, and other statistical calculations. This method was adopted as it is termed to be highly accurate. The data for this study was obtained from KPMG International (Tax) Bulletin report on fifty (50) major corporate organizations in Nigeria for 2014 to 2018. Five years' data transactions on transfer pricing policies in terms of its influence on the Organizations' Business Growths (OBG) which is the dependent variable (regressed) and the Annual Tax Rate (Txr), Annual Profit Rate (Pfr) and Annual Tax Liability (Txl) which are the independent variables (regressors) are used. Regression analysis was adopted for this study for estimating the relationships among variables.

\subsection{Model Specification}

A regression model relates $Y$ to a function of $X$ and $\beta$.

$$
Y \approx f(X, \beta)
$$

Where $\beta$ is the unknown parameter, $X$ is the independent variable and $Y$ is the dependent variable.

For this study, a model was developed to analyze the influence of transaction transfer pricing policies on the corporate organization in Nigeria using Organizations' Business Growths as the dependent variable and the Annual Tax Rate, Annual Profit Rate and Annual Tax Liability as the independent variables. The study hence employed the model as specified below:

$$
\begin{gathered}
Y=\beta_{0}+\beta_{1} X_{1}+\beta_{2} X_{2}+\beta_{3} X_{3}+\cdots+\varepsilon_{i} \quad(i=1, \ldots \ldots, n) \\
\text { i.e., } O B G=f\left(T_{x r}, P_{f r}, T_{x l}, \beta\right)
\end{gathered}
$$

The modification for this study is thus,

$$
O B G=\beta_{0}+\beta_{1} T_{x r}+\beta_{2} P_{f r}+\beta_{3} T_{x l}+\varepsilon_{i}
$$

Where:

$Y(O B G)$ Represent the influence of transaction transfer pricing policies on corporate organizations in Nigeria in terms of the Organizations' Business Growth between 2014 and 2018.

$\beta_{0}$ Represent the Regression Constant term.

$\beta_{1}$ Represent the partial regression co-efficient of annual tax rate

$\beta_{2}$ Represent the partial regression coefficient of the annual profit rate

$\beta_{3}$ Represent the partial regression coefficient of the annual tax liability

$X_{1}\left(T_{x r}\right)$ Represent the Annual Tax Rate influence due to the transaction transfer pricing policies of the organizations.

$X_{2}\left(P_{f r}\right)$ Represent the Annual Profit Rate of corporate organizations.

$X_{3}\left(T_{x l}\right)$ Represent the reported Annual Tax Liability of corporate organizations.

$\varepsilon$ Represent the Random Error term/Residuals.

\subsection{Results}

4.1 Transaction transfer pricing policies among corporate organizations (adopted)

\begin{tabular}{|l|l|}
\hline Transaction transfer pricing compliance & $\begin{array}{l}\text { Average level }-70 \% \\
\text { High level }-30 \%\end{array}$ \\
\hline Annual transaction transfer pricing policies evaluation (2014-2018) & All years $-74 \%$ \\
& Some of the years $-22 \%$ \\
& No $-4 \%$ \\
\hline Internal transaction transfer pricing policies in place & Yes $-88 \%$ \\
& No $-10 \%$ \\
& Not applicable $-2 \%$ \\
\hline
\end{tabular}

Source: Transaction transfer pricing policies among corporate organizations of Nigeria, (2020).

The table above shows the attitude of the corporate organizations in Nigeria which data was retrieved and 
adopted for this study to transaction transfer pricing policies. An average value of 70 per cent indicated compliance with transaction transfer pricing policies while 30 per cent indicated a high level. For the years 2014-2018, 74 per cent indicated a yearly evaluation of their organizations' pricing policies while 88 per cent shows that there are internal transaction transfer pricing policies in place in their respective corporate organizations. This is an indication of high-level awareness of transaction transfer pricing policies among the corporate organizations in Nigeria and also an indication of knowledge of applicable penalties that may arise in the event of non-compliance of transaction transfer pricing policies requirements.

\begin{tabular}{lrrrr} 
4.2 Descriptive Analysis & \multicolumn{1}{c}{ Txr } & \multicolumn{1}{c}{ Pfr } & \multicolumn{1}{c}{ Txl } \\
\hline Mean & 29.92 & 41.83916 & 13.1452 & 22.63182 \\
Standard Error & 0.312776 & 1.20202 & 0.760296 & 1.057458 \\
Median & 30 & 43.23 & 12.06 & 20.1265 \\
Mode & 30 & 54.16 & 12 & 25 \\
Standard Deviation & 2.211657 & 8.499567 & 5.376101 & 7.477356 \\
Sample Variance & 4.891429 & 72.24265 & 28.90247 & 55.91086 \\
Kurtosis & 0.151935 & -0.71199 & 0.434581 & 0.341205 \\
Skewness & 0.211341 & -0.42785 & 0.446056 & 0.910373 \\
Range & 10 & 32.36 & 25.4 & 28.2 \\
Minimum & 25 & 24.06 & 3.5 & 12 \\
Maximum & 35 & 56.42 & 28.9 & 40.2 \\
Sum & 1496 & 2091.958 & 657.26 & 1131.591 \\
Count & 50 & 50 & 50 & 50 \\
\hline
\end{tabular}

Source: Researchers' Descriptive Analysis Outputs, (2020).

The descriptive analysis of the influence of transaction transfer pricing policies on corporate organizations in Nigeria between 2014 - 2018 using tax rate (Txr), profit rate (Pfr) and tax liability (Txl) as indictors on the organizations business growth (OBG) is shown in table 4.1 above. The calculated values showed a Mean of 29.92, 41.84, 13.15 and 2.63; Standard Deviation of 2.212, 8.499, 5.376 and 7.477; Kurtosis of 0.15, -0.71, 0.43 and 0.34 and Skewness of $0.211,-0.427,0.446$ and 0.910 among others. The profit rate has a negative value of -0.47 in the calculated Skewness hence there was a continuous fluctuation in the profit rate yearly. This is also in conformity with the Kurtosis calculated value of -0.711 for the profit rate.

4.3 Regression Analysis

Hypothesis One

$\mathrm{H}_{0}$ : Transactional transfer pricing policies have no significant influence on corporate organizations in Nigeria.

\begin{tabular}{|c|c|c|c|c|c|c|}
\hline \multicolumn{2}{|c|}{ Regression Statistics } & & & & & \\
\hline Multiple R & 0.212748293 & & & & & \\
\hline R Square & 0.452618363 & & & & & \\
\hline Adjusted R Square & 0.170036961 & & & & & \\
\hline Standard Error & 7.540659748 & & & & & \\
\hline Observations & 50 & & & & & \\
\hline \multicolumn{7}{|l|}{ ANOVA } \\
\hline & $d f$ & $S S$ & $M S$ & $F$ & Significance F & \\
\hline Regression & 3 & 124.0007774 & 41.33359 & 1.2526916 & 0.0124116597 & \\
\hline Residual & 46 & 2615.631274 & 56.86155 & & & \\
\hline \multirow[t]{2}{*}{ Total } & 49 & 2739.632051 & & & & \\
\hline & Coefficients & Standard Error & $t$ Stat & $P$-value & Lower 95\% & Upper 95\% \\
\hline Intercept & 47.56688663 & 16.95549518 & 2.805396 & 0.007341 & 13.43724501 & 81.69653 \\
\hline Txr & -0.727162218 & 0.523654066 & 1.38863 & 0.111633 & -1.781223183 & 0.326899 \\
\hline Pfr & -0.097491577 & 0.13743922 & 0.70934 & 0.081692 & -0.374142378 & 0.179159 \\
\hline Txl & 0.06851114 & 0.224711099 & 0.304885 & 0.061829 & -0.383808843 & 0.520831 \\
\hline
\end{tabular}

Source: Researcher's Regression Analysis Outputs, (2020).

The table above shows the Regression Statistics and ANOVA of the annual tax rate, profit rate and tax liability as influenced by transaction transfer price policies in corporate organizations in Nigeria covering the period of 2014 - 2018. The coefficient of determination (R square) value of 0.452618363 was reported which indicated that $45 \%$ of the model and dependent variables have a good strength of the relationship. The reported F-statistics value of 1.2526916 having a significant level value of 0.0124116597 reported from the model adopted indicated that the model was very significant since its F-value is greater than the recommended 0.05 . The P-values calculated for tax 
rate, profit rate and tax liability are $0.111633,0.081692$ and 0.061829 respectively which indicated that there is a good influence of the dependent variable on corporate organizations. The calculated P-values are below the recommended $0.15 \mathrm{P}$-value to be termed significant. The result obtained from the regression analysis showed there is a high positive intercept value of 47.56688663, an indication of the high influence of transaction transfer pricing of corporate organizations in Nigeria. However, insignificant T-stat values were calculated, evidence that the Txr, Pfr and Txl values calculated are not significantly different from its influence on the corporate organization using OBG in proxy as used in the study. The significance F-value (F-sig) of 0.012 reported indicated that the null hypothesis $\left(\mathrm{H}_{0}\right)$ "Transactional transfer pricing policies has no significant influence on corporate organizations in Nigeria" is not true. Therefore, the $\mathrm{H}_{1}$ hypothesis "Transactional transfer pricing policies have a significant influence on corporate organizations in Nigeria" is supported are termed true.

\subsection{Conclusion}

The influence of transaction transfer pricing policies among corporate organization in Nigeria was studied using secondary data obtained from KPMG International (Nigeria) annual reports for the year 2014-2018 and analyzed using Origin61, a statistical software adopting regression analysis and descriptive analysis models. Hence the Tax Rate (Txr), Profit Rate (Pfr), Tax Liability (Txl) and Organizations' Business Growth (OBG) were regressed. The results obtained showed that the parameters adopted for the study have a significant influence on corporate organizations in Nigeria. It is therefore concluded that transaction transfer pricing policies adopted by organizations have a significant positive influence on the growth of the organization in Nigeria, a model that can be adopted worldwide.

The study then recommends that corporate organization should employ adequate measure that safeguards are in place to avoid costly error in the implementation of transaction transfer pricing policies. Such measure may include ensuring that a transaction transfer pricing specialist track and compile all relevant transaction documentation and supporting documents to defend the arm's length nature of the corporate organization's related party transactions. Also, due to the negative Skewness and Kurtosis calculated for the study, the corporate organization may outsource transaction transfer pricing function to specialists who can assist the corporate organizations in mitigating transaction transfer pricing risks.

\section{References}

Aaron S. E \& Stefan J. R. (1995). "Specific Investment under Negotiated Transfer Pricing: An Efficiency Result." The Accounting Review, available at http://works.bepress.com/aaron_edlin/4/.

Abu-Serdaneh, J. A., Al-Okdeh, S. K. \& Gauher, K. A. (2008). "Transfer Pricing in Jordanian Manufacturing Companies." Jordan Journal of Business Administration, 11, 313-330.

Adams, L \& Drtina, R. (2010). "Multinational Transfer Pricing: Management Accounting Theory versus Practice." Management Accounting Quarterly, 11(3).

Adum, O. S. (2015). “The Impact of Transfer Pricing on Financial Reporting: A Nigerian Study.” Research Journal of Finance and Accounting, 6 (16): 208-218.

Allen, D. W. (1999). "Transaction Costs." Encyclopedia of Law and Economics.

Blocher, E, Stout, D. E., Cokins. G. \& Chen, K. (2006). “Cost Management: A Strategic Emphasis”, (4 ${ }^{\text {th }}$ Edition), ISBN 13: 9780073128153.

Carbaugh, R. J. (2006). “Contemporary Economics: An Applications Approach.” Cengage Learning. ISBN 9780-324-31461-8.

Clausing, K. A. (2012). "Who Pays the Corporate Tax in a Global Economy?". National Tax Journal. 66 (1). SSRN 2213581.

Companies $\quad$ Income $\quad$ Tax Amendment) Act. Available at https://placng.org/new/laws/COMPANIES\%20INCOME\%20TAX\%20_AMENDMENT_\%20ACT,\%2020 07.pdf

Cooper, J., Fox, R., Leoprick, J. \& Mohindra, K. (2016).”Transfer Pricing and Developing Economies : A Handbook for Policy Makers and Practitioners", Washington DC; World Bank, 18-21. ISBN 978-1-46480970-5.

Crosby, P. B. (1990). “The Eternally Successful Organization: The Art of Corporate Wellness.” New York: New American Library.

Dean, M., Feucht, F. J. \& Smith, M. (2008). "International Transfer Pricing. Issues and Strategies for the Global Firm." Internal Auditing, 23(1): 12-19.

Dubin, J. A. (2004). "Criminal Investigation Enforcement Activities and Taxpayer Non-compliance." Paper presented at 2004 IRS Research Conference, Washington, 1-45.

Dürr, O. M. \& Göx, R. F. (2013). "Specific Investment and Negotiated Transfer Pricing in an International Transfer Pricing Model." Schmalenbach Business Review, 65, 27-50.

Falk, D. (2010). “Transfer Pricing: Alternative Practical Strategies". 19 ${ }^{\text {th }}$ Tax Management (BNA) Transfer Pricing 
Report at 89 Measuring and Monitoring BEPS.

Gupta, P. (2012). “Transfer Pricing: Impact of Taxes and Tariffs in India”. Vikalpa, 37(4), 29.

KPMG International, Nigeria (2017). Transfer Pricing Awareness Survey, An Annual Reports. https://assets.kpmg/content/dam/kpmg/ng/pdf/tax/ng-transfer-pricing-awareness-survey.pdf

Lipton, M. (2003). “Guiding Growth: How Vision Keeps Company on Course.” Harvard Business School Press.

Liu, Li (2011). "The economic effects of corporate income taxation." (PhD Thesis). doi:10.7282/T3765DZR.

Mckinley J. \& Owsley J. (2013). "Transfer Pricing and its Effects on Financial Reporting”. Journal of Accountancy, https:/www.journalofaccountancy.com/issues/2013/oct/20137721.html.

Mutua, N. (2012). "Transfer Pricing Management Strategies by MNEs within the Main Investments Segment of NSE.” MBA Research Project, University of Nairobi, 23-26.

Nilufer, U. (2012). "Transfer Prices: A Financial Perspective". Journal of International Financial Management \& Accounting 23(1). DOI: 10.1111/j.1467-646X.2011.01052.x.

OECD (2010). "Transfer Pricing Guidelines for Multinational Enterprises and Tax Administrations" pp.18. doi:10.1787/tpg-2010-en. ISBN 978-92-64-09018-7.

OECD (2018)."Guidance on Application of the Profit Split Method Provides, The objective of action 10 in the OECD's BEPS Action Plan (Revised Version)". https:/www.pwc.com/gx/en/services/tax/tax-policyadministration/beps/transfer-pricing-and-other-high-risk-transactions.html (retrieved July 27, 2019).

OECD (2019). "Manual on Effective Mutual Agreement Procedures (MEMAP)", available on http://oecd.org/tax/dispute/manualoneffectivemutualagreementproceduresmemap.html.

Ordu, P. A. \& Anele, C. A. (2015). “A Performance Analysis of Nigerian Tax Objectives Actualization: Evidence of 2000 - 2012." International Journal of Management Science and Business Administration, 1 (6): 88-100.

Oyunda, A. (2015). "Tax Administration, Compliance and its Effect on Financial Reporting." Journal of Business and Management, 2: 21-26.

Piper, M. (2014). “Taxes Made Simple: Income Taxes Explained in 100 Pages or Less.” Simple Subjects, LLC. ISBN 978-0981454214.

Savita, A. S. (2003). "Transfer Pricing Based on Actual Cost.” Journal of Management Accounting Research: December 2003, 15 (1): 177-192.

Singh, D. P. (2015). "Calculation of Arm's Length Price-Section 92C of Income Tax Act 1961" .https://taxguru.in/income-tax/calculation-arms-length-pricesection-92c-income-tax-act-1961.html (retrieved July 22, 2019).

Steven, A. B. (2011). "Anglo-American Corporate Taxaion: Tracing the Common Roots of Divergent Approaches". Cambridge University Press, 28-29.

Tanzi, V. (2000). "Globalization, Technological Developments and the Work of Fiscal Termites (WP/00/181)". International Monetary Fund, Washington DC.

Tebogo, B. (2011). "The Transfer Pricing Problem: When Multinational Corporations Shift Profits Across International Borders.” https://papers.ssrn.com/sol3/papers.cfm?abstract_id=1899014.

Uthman, S. (2016). "Adoption of IFRS in Nigeria and Implementation Challenges." Available on https://linkedin.com/pulse/adoption-ifrs-nigeria-its-post-implementation-uthman-saheed/.

Williams, D. F. (2007). “Tax and Corporate Social Responsibility.” Discussion paper of KPMG's Tax Business School. 